\title{
Discovery of a Possibly Relict Outbreeding Morphotype of Sparrow's-egg Lady's-slipper Orchid, Cypripedium passerinum, in Southwestern Yukon
}

\author{
Paul M. Catling ${ }^{1}$ and Bruce A. BennetT ${ }^{2}$ \\ ${ }^{1}$ Agriculture and Agri-Food Canada, Environmental Health, Biodiversity, Wm. Saunders Building, Central Experimental Farm, \\ Ottawa, Ontario, Canada K1A 0C6 e-mail: catlingp@agr.gc.ca \\ ${ }^{2}$ Department of Environment, Government of the Yukon, Box 2703, Whitehorse, Yukon, Canada Y1A 2 C6 e-mail: Bruce. \\ Bennett@gov.yk.ca
}

Catling, Paul M., and Bruce A. Bennett. 2007. Discovery a possibly relict outbreeding morphotype of Sparrow's-egg Lady'sslipper Orchid, Cypripedium passerinum, in southwestern Yukon. Canadian Field-Naturalist 121(3): 295-298.

An outbreeding morphotype of Cypripedium passerinum with separate anthers and stigma was discovered in the Beringian region of southwesternYukon. The occurrence of this breeding system in Beringia is attributed to the persistent advantage of outbreeding over hundreds of thousands of years in this unglaciated area, whereas the widespread occurrence of exclusively self-pollinating races elsewhere in Canada is attributed to advantages in colonization of recently deglaciated territory which first became available less than 10000 years ago, and/or to a changing and more forested habitat.

Key Words: Sparrow's-egg Lady's-slipper Orchid, Cypripedium passerinum, Orchidaceae, autogamy, self-pollination, unglaciated, Beringia, Kluane, Yukon.

In fresh flowers of Sparrow-egg Lady's-slipper Orchid (Cypripedium passerinum Richards.), the lateral parts of the stigma are in contact with the anther allowing self-pollination (Figure 1A). Self-pollination is evident by a mass of pollen tubes connecting the expanded anther tightly to the stigmatic surface. It occurs when the flowers are still in bud or before they are fully open and germination of pollen prevents subsequent removal by pollinators resulting in little chance for cross-pollination. This obligate self-pollination is widespread (Catling 1983; Catling, personal observation) in the geographic range, which extends from Quebec west across the boreal forest and montane region of Canada to Alaska (Sheviak 2002; Figure 2). Plants that do not self-pollinate have not been observed prior to the observations reported here.

An examination of long-faded and shrivelled flowers, clearly past peak flowering, collected in alcohol on 13 July 2006 from the Alsek River trail $\left(60.7748^{\circ} \mathrm{N}\right.$, $-137.6939^{\circ} \mathrm{W}$, approximately $10 \mathrm{~km}$ west of Haines Junction) in the Kluane Range, St. Elias Mountains of southwestern Yukon, revealed that self-pollination had not occurred in 7 of 8 flowers removed from a clump of 30 . In most of these flowers self-pollination was prevented because the anthers were clearly separated from the stigmatic surface (Figures 1B-C) but in one flower they were touching but without self-pollination (Figure 1D) and the anthers were bowed so that most of the length of the suture was not in contact with the stigmatic surface. In one of these flowers self-pollination had occurred apparently due to contact of anther and stigma (Figure 1E). All eight of the flowers from this clump were presumably from one individual and sug- gest variation in self-pollination at the individual level. A voucher specimen (Catling \& Bennett, 13 July 2006) from the Alsek River location has been placed in the National Collection (acronym - DAO) of Agriculture and Agri-Food Canada on the Central Experimental Farm in Ottawa.

Ten long-faded flowers collected from several individual plants south of Whitehorse at Cowley Creek $\left(60.5908^{\circ} \mathrm{N}, 134.8953^{\circ} \mathrm{W}\right)$ were self-pollinated (Figures $1 \mathrm{~F}-\mathrm{H}$ ) and so were three flowers collected from a location near Mayo (not illustrated). In one of the flowers from Whitehorse an anther was sufficiently separated that self-pollination had not occurred (Figure $1 \mathrm{~F})$. Although only the distal tip of the anther suture appeared to contact the stigmatic surface in most specimens, in one flower (Figure 1G) the proximal part had also come in contact, with the result that pollen tubes entered the stigma from both anther tips. Self-pollination in orchids is frequently partial or facultative (e.g., Catling 1990). In western Yukon there may be substantial variation in column morphology leading to variation in amounts of self-pollination, both within individuals and between plants. This variation may have provided the basis for the selection of obligate selfpollinating morphotypes that are now widespread.

Selection for self-pollination may have favoured a number of characteristics including: (1) more extensive development of the lateral parts of the stigmatic surface; (2) less divergence of the anther stalks; (3) less elongation and curvature of the column resulting in less displacement of the anthers above the stigmatic surface; (4) increased bowing of the anthers to bring the tips of the suture into contact with the stigmatic sur- 

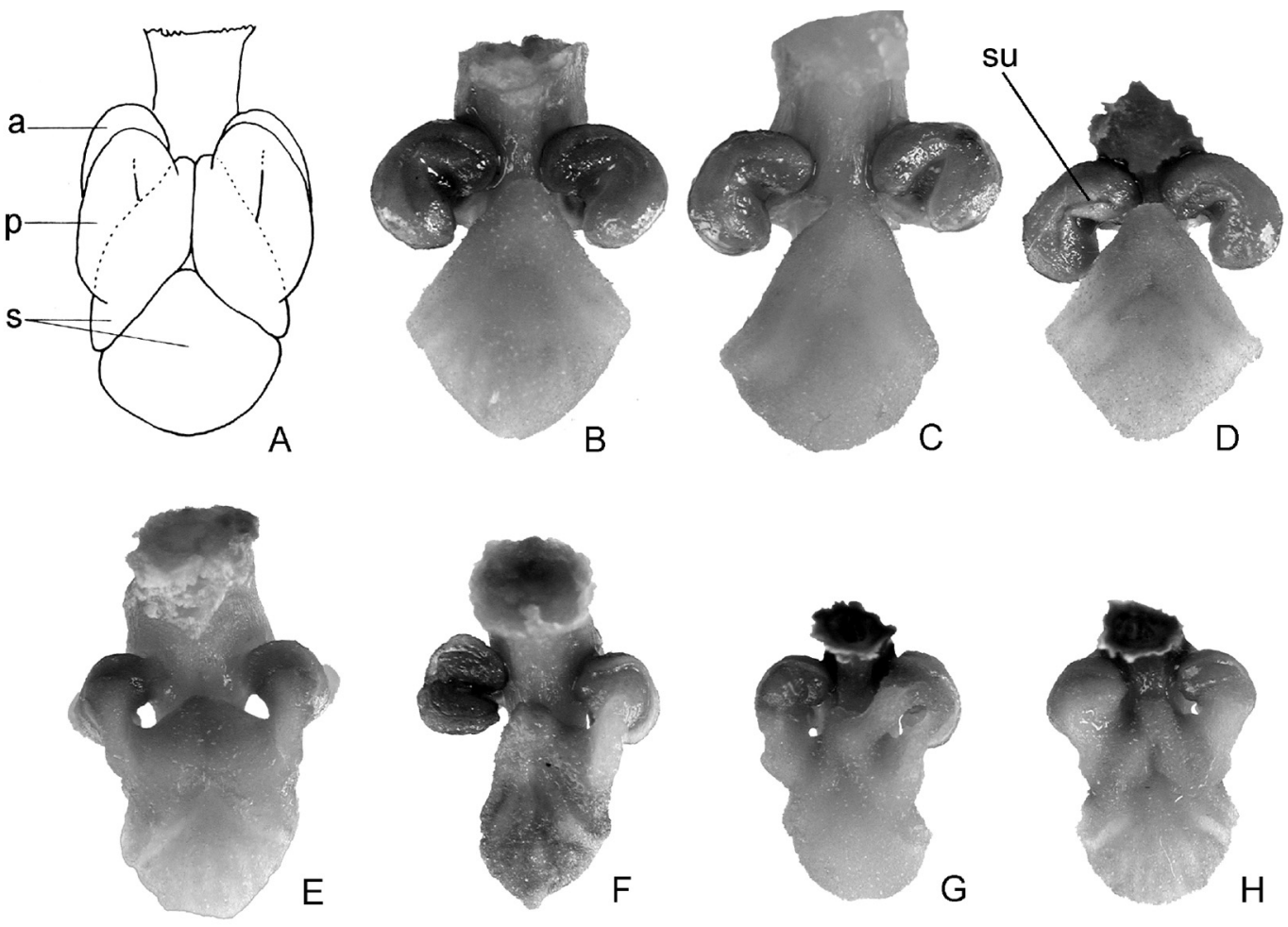

$5 \mathrm{~mm}$

FIGURE 1. Columns of Cypripedium passerinum viewed from below showing anthers (a), pollinia (p), stigmatic surface (s) and suture of anther (su). A, camera lucida drawing of flower from Hattie Cove, Lake Superior, Ontario (modified from Catling 1983); B-E flowers from Alsek trail, Kluane Range, Yukon; F-H, flowers from south of Whitehorse, Yukon. Columns A and E-H demonstrate self-pollination with one or both anthers connected to the stigmatic surface by a mass of pollen tubes. Columns B-D have not self-pollinated.

face; and (5) increased secretion of stigmatic fluid which would connect the anther and the stigma. Regardless of how the flowers have changed to promote self-pollination, both the separation of anther and stigma, and the lack of self-pollination in old flowers are novel observations suggesting outbreeding in a species that was hitherto known only to obligately self-pollinate.

The structure related to breeding system in C. passerinum is difficult to discern in reconstituted pressed herbarium specimens and softening the few flowers on a specimen to evaluate it results in damage to the specimen. As a consequence, an investigation of herbarium material was not conducted. The examination of fresh plants from at least 20 localities (Catling, personal observation) across Canada, including Ontario (3 locations), Manitoba (1 location), British Columbia (8 locations), Alberta (2 locations) and Northwest Territories (6 locations) is believed to reliably indicate the predominance of the obligately self-pollinating morphotype outside of the Beringian region (Figure 2).
Nevertheless, more research on the geographical occurrence and related morphological and anatomical aspects is needed to better understand the evolution of self-pollination in this species, and to provide a basis for consideration of formal taxonomic recognition.

Self-pollination originates through evolution by natural selection from cross-pollinated plants (e.g., Catling 1990). In general, self-pollination in orchids is more frequent in cooler and more extreme environments such as recently glaciated territory (Catling 1983, 1990). This is believed to be a consequence of strong selection for colonizing ability, the selfing plants being able to set seed in the absence of others of their kind and/or in the absence of pollinators and being able to mass produce adapted genotypes. This would have been advantageous in colonizing huge areas of land (most of northern North America) exposed following melting of the Wisconsin ice sheets less than 10000 years ago (Dyke 2005). It may also be advantageous within Beringia as a consequence of the change from pollinator-rich willow (Salix spp.) scrub and tundra to 


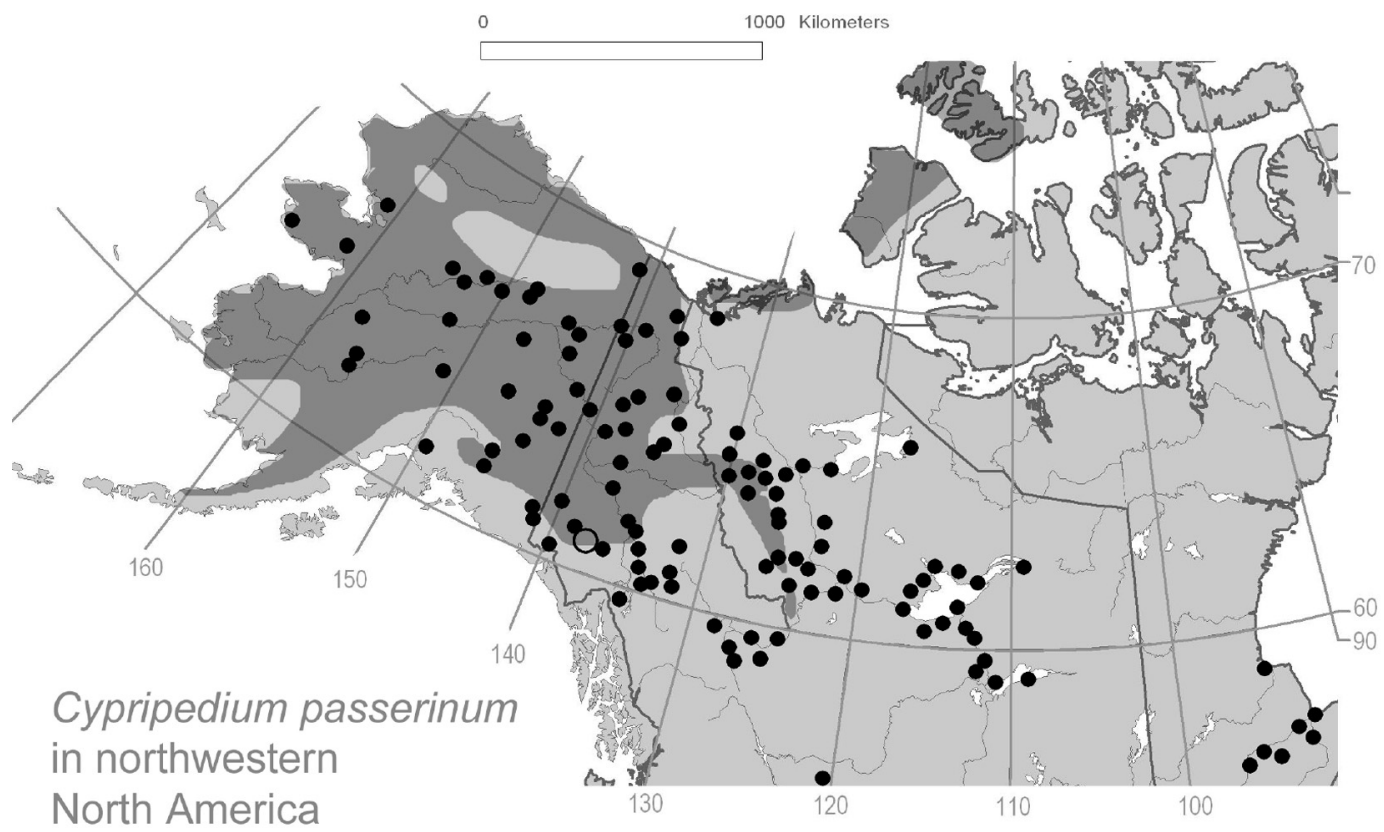

FIGURE 2. Distribution of Cypripedium passerinum in northwestern North America (dots) and location of plants with non-autopollinating column structure on Alsek River (circle). The unglaciated region of Beringia is darkly shaded (redrawn from Dyke 2005). The dot distribution of C. passerinum was copied from Cody (1996), Hultén (1968), Packer (1959), Porsild and Cody (1980), and Szczawinski (1959).

a pollinator-depauperate boreal forest that occurred between 9000 and 5000 ka kiloannum BP (Dyke 2005). As a result of the strong selection, self-pollinating morphotypes are presumed to have evolved from cross-pollinated ancestors in unglaciated territory, and these new selfers spread over the newly available or recently changed landscape. Many self-pollinating orchids have a non-self-pollinating relative that has a more restricted range in a region of more temperate climate and/or longer established habitat. Examples in North America include self-pollinating Liparis loeselii which is widespread north of the range of the non-self-pollinating Liparis liliifolia, and self-pollinating Spiranthes ovalis var. erostellata which is widespread north of the more restricted distribution of Spiranthes ovalis var. ovalis (see Catling 1990 for other examples).

The occurrence of a non-self-pollinating race of Cypripedium passerinum in the northwestern part of the range rather than the warmer southern or southeastern part of its range is at first contrary to expectation. However, in this example a relict outbreeding morphotype may have existed for hundreds of thousands of years in the unglaciated Beringian area of Alaska and western Yukon (Figure 2 and see Scudder 1997). It may have been from this source that morphotypes more committed to self-pollination spread southward and eastward following deglaciation 10000 years ago. The present distribution of Cypripedium passerinum fits what Hultén refers to as "North American boreal plants radiating from Beringia." (Hultén 1937, see also Cody 1971 and Ritchie 2003). It is possible that the outbreeding ancestral morphotype of Cypripedium passerinum is a Beringian relict. In Beringian habitats that have existed for hundreds of thousands of years, and presumably include pollinators, cross-pollination was likely advantageous. Cypripedium passerinum presently occurs in Alnus crispa or Betula glandulosa shrubland habitats that are believed to have existed in Beringia during full glacial times (e.g., Hopkins 1982; Ritchie and Cwynar 1982; Cwynar 1990; Cwynar and Spear 1991; Lacourse and Gajewski 2000) when the rest of Canada was covered by ice up to a few $\mathrm{km}$ deep. Cypripedium passerinum also occurs in open aspen (Populus) and spruce (Picea) woodland. Both of these species evidently existed in isolated valley-bottom habitats within the Beringian steppe plateaus, although Populus pollen does not preserve well making its widespread but isolated occurrences more difficult to detect (Zazula et al. 2006; Zazula, personal communication). Cypripedium passerinum also occurs in parts of the north, to $68^{\circ} \mathrm{N}$, where Beringian species are predominant. As it spread from Beringia across the rest of northern Canada into new, recently deglaciated territory, there 
was likely a strong selection for self-pollination, this explaining the apparent predominance of self-pollinating morphotypes.

\section{Literature Cited}

Catling, P. M. 1983. Autogamy in eastern Canadian Orchidaceae: a review of current knowledge and some new observations. Le Naturaliste canadien 110: 37-53.

Catling, P. M. 1990. Auto-pollination in the Orchidaceae. Pages 121-158 in Orchid Biology, reviews and perspectives V. Edited by J. Arditti. Timber Press, Oregon. 451 pages.

Cody, W. J. 1971. A phytogeographic study of the floras of the Continental Northwest Territories and Yukon. Le Naturaliste canadien 98: 145-158.

Cody, W. J. 1996. Flora of the Yukon Territory. NRC Research Press, Ottawa, Ontario. 643 pages.

Cwynar, L. C. 1990. A late quarternary vegetation history from Lily Lake, Chilkat Peninsula, southeast Alaska. Canadian Journal of Botany 68: 1106-1112.

Cwynar, L. C., and R. W. Spear. 1991. Reversion of forest to tundra in the central Yukon. Ecology 72: 202-212.

Dyke, A. S. 2005. Late quaternary vegetation history of northern North America based on pollen, macrofossil, and faunal remains. Géographie physique et Quaternaire 59: 211 162.

Hopkins, D. M. 1982. Aspects of the paleogeography of Beringia during the late Pleistocene. Pages 3-28 in Paleoecology of Beringia. Edited by D. M. Hopkins, J. V. Matthews Jr., C. E. Schweger, and S. B.Young. Academic Press, New York, New York.

Hultén, E. 1937. Outline of the history of Arctic and Boreal biota during the Quartenary Period: their evolution during and after the glacial period as indicated by the Equiformal Progressive Areas of Present Plant Species. Bokförlags Aktiebolaget Thule, Stockholm. 167 pages.
Hultén, E. 1968. Flora of Alaska and neighbouring districts. Stanford University Press, Stanford, California. 1008 pages.

Lacourse, T., and K. Gajewski. 2000. Late Quaternary vegetation history of Sulphur Lake, southwest Yukon Territory, Canada. Arctic 53: 27-35.

Packer, J. G. 1959. Flora of Alberta, 2nd edition. University of Toronto Press, Toronto, Ontario. 687 pages.

Porsild, A. E., and W. J. Cody. 1980. Vascular plants of continental Northwest Territories. National Museum of Natural Sciences, Ottawa, Canada. 667 pages.

Ritchie, J. C. 2003. Postglacial vegetation of Canada. Cambridge University Press, Cambridge, UK. 178 pages.

Ritchie, J. C., and L. C. Cwynar. 1982. The late Quaternary vegetation of the North Yukon. Pages 113-126 in Paleoecology of Beringia. Edited by D. M. Hopkins, J. V. Matthews Jr., C. E. Schweger, and S. B. Young. Academic Press, New York, New York.

Scudder, G. G. E. 1997. Environment of the Yukon. Pages 13-57 in Insects of the Yukon. Edited by H. V. Danks and J. A. Downes. Biological Survey of Canada Monograph Series (2): 1034 pages.

Sheviak, C. J. 2002. 1. Cypripedium Linnaeus. Pages 499507 in Flora of North America volume 26. Edited by Flora of North America Editorial Committee. Oxford University Press, New York. http://www.efloras.org/object_page.aspx? object_id=8891\&flora_id=1.

Szczawinski, A. 1959. Orchids of British Columbia. British Columbia Provincial Museum Handbook (16): 1-124.

Zazula, G. D., A. M. Telka, C. R. Harington, C. E. Schweger, and R. W. Mathewes. 2006. New spruce (Picea spp.) macrofossils from Yukon Territory: implications for late Pleistocene refugia in eastern Beringia. Arctic 59: 391-400.

Received 22 January 2007

Accepted 14 July 2008 